\title{
Original paper \\ Modified chromatographic separation scheme for Sr and Nd isotope analysis in geological silicate samples
}

\author{
Jitka MíKOVÁ*, Petra DENKOVÁ \\ Czech Geological Survey, Klárov 3, 11821 Prague 1, Czech Republic; jitka.mikova@geology.cz \\ * Corresponding author
}

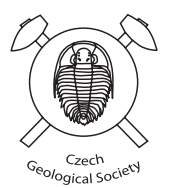

A novel chromatographic separation technique for $\mathrm{Sr}$ and $\mathrm{Nd}$ separation from geological silicate samples was established and successfully tested for routine use in Laboratory of Radiogenic Isotopes of the Czech Geological Survey. The separation scheme is based on combination and modification of methods published in papers by Christian Pin and his co-workers. This triple column arrangement enables the isolation of pure $\mathrm{Sr}$ and $\mathrm{Nd}$ fractions (also Sm if required) from bulk-rock solution in a single step during one working day. The $\mathrm{Sr}$ and Nd yields are high, while blank levels remain low. This procedure minimizes the acid consumption and time needed for the separation by more than half compared to the traditional ion exchange separation techniques. The calibration of the Ln.Spec columns should be periodically monitored because the elution of REEs shifts after a period of extensive use of the resin. Suitability of this technique for $\mathrm{Sr}$ and $\mathrm{Nd}$ separation from silicate rock samples was confirmed by repeated measurements of ${ }^{87} \mathrm{Sr} /{ }^{86} \mathrm{Sr}$ and ${ }^{143} \mathrm{Nd} /{ }^{144} \mathrm{Nd}$ isotopic ratios in three international reference materials BCR-1, JA-1 and JB-3.

Keywords: strontium, neodymium, ion exchange chromatography, isotopic analysis, silicate rocks; thermal-ionization mass spectrometry Received: 12 October 2007; accepted 15 December 2007; handling editor: M. Štemprok

\section{Introduction}

The measurements of isotopic composition performed by thermal ionization mass spectrometry (TIMS) require chemical separation of the elements of interest. This is important as an impure sample will give both a very poor ion yield and cause beam instability in the mass spectrometer, potentially resulting in a poor analysis. Isobaric interferences, such as ${ }^{87} \mathrm{Rb}^{+}$and ${ }^{87} \mathrm{Sr}^{+}$must also be minimized for accurate isotopic determination.

This separation is traditionally performed using ion exchange chromatography. Since the early pioneering work of Aldrich et al. (1953), the chromatographic techniques have proven to be the most useful for isolating elements of interest from the sample matrix. Although this technique is widely used in isotope geochemistry, conventional ion exchange resins have a disadvantage of the poor elemental selectivity. In general, chromatographic separation schemes are based on differences in distribution coefficients (the larger the coefficient, the greater the affinity of the ion to the resin, also the larger the ratio of the coefficients of two different ions, the easier it is to separate them using ion exchange). They, therefore, require relatively large ion exchange columns and chemical reagent volumes, depending on the sample size. Previously, we have employed traditional ion exchange separations (Richard et al. 1976) using Bio-Rad AGW X8 (200-400 mesh) resin and decomposed sample in $2.5 \mathrm{M}$ $\mathrm{HCl}$ solution to separate $\mathrm{Rb}$ and $\mathrm{Sr}$. For a sample weight of c. $100 \mathrm{mg}$ the volumes of reagents required to elute $\mathrm{Sr}$ were $60 \mathrm{ml}$ of $2.5 \mathrm{M} \mathrm{HCl}$; the $\mathrm{Sr}$ fraction was collected in the last $c .15 \mathrm{ml}$ of this volume. Additional $50 \mathrm{ml}$ of $6 \mathrm{M}$ $\mathrm{HCl}$ were required to elute REEs, which were collected in the last $10 \mathrm{ml}$ of that volume. The REE fraction was then evaporated and dissolved in $0.2 \mathrm{M} \mathrm{HCl}$. Finally, $\mathrm{Nd}$ was separated by passing the sample through another column packed with BioBeads S-X8, 200-400 mesh beads coated with DEP - bis(2-ethylhexyl) hydrogen phosphate. The total volume of acids required to elute $\mathrm{Nd}$ was $c .40 \mathrm{ml}$.

A new generation of chromatographic resin materials developed at the Argonne National Laboratory (USA) helps to solve many of the difficulties with large amounts of reagents and long time required for separation some of the geochemically important elements. These resins were originally designed for separation of radioactive nuclides from nuclear waste solutions but their high capacity and specificity make them suitable also for environmental and geological applications. Here we present a separation scheme for strontium and neodymium applicable to isotopic analysis of silicate rocks. This separation procedure is based up on combination and slight modification of methods published in papers by Pin et al. (1994) and Pin and Zalduegui (1997). The first paper describes the separation procedure for $\mathrm{Sr}$ using the Sr.Spec and the separation of LREEs using the TRU.Spec resins from silicate samples, while the second paper describes the separation of individual light rare elements using the Ln.Spec resin. 


\section{Experimental}

\subsection{Reagents}

All acids ( $\left.\mathrm{HF}, \mathrm{HNO}_{3}, \mathrm{HCl}\right)$ used were of analytical reagent grade and were further purified by sub-boiling distillation in silica glass or PTFE stills. Water was purified using a NANOpure system, Barnstead Corporation (resistivity: $18 \mathrm{M}^{\prime} \Omega \mathrm{cm}$ ).

The three chromatographic materials used in this procedure, referred to as Sr.Spec, TRU.Spec and Ln.Spec, were obtained from Eichrom Environment (Bruz, France). All were fine-grained (50-100 $\mu \mathrm{m}$ particle size) materials. Ion exchange resins were cleaned before the use by alternating deionised water and acids used as elution agents for elements of interest (specific for each of the resins).

\subsection{Columns}

In order to minimize the costs of analysis, we decided to use modified $1 \mathrm{ml}$ Plastic (PE) Pasteur pipettes as columns rather then purchasing ready made columns made of quartz glass or PTFE. The tops of the pipette bulbs were cut off to leave a reservoir of approximately $5 \mathrm{ml}$ in volume and the length of the stem was shortened to obtain the required volume for ion exchange resin. To keep the resin in place, the bottoms of the column tips were closed by inserting $30 \mu \mathrm{m}$ polyethylene frits $4 \mathrm{~mm}$ in diameter (i.d.).

The Sr.Spec and TRU.Spec columns (4 mm i.d., $2.5 \mathrm{~cm}$ long) were made using a $0.25 \mathrm{ml}$ portion of precleaned Sr.Spec and TRU.Spec resins respectively. The resin was discarded after each sample.

The Ln.Spec columns (4 mm i.d., $8.5 \mathrm{~cm}$ long) were prepared using $0.9 \mathrm{ml}$ of the preconditioned resin. The tops of the ion exchange resin in columns were closed by a second frit. These columns were stored in $0.2 \mathrm{M} \mathrm{HCl}$ and used repeatedly.

\subsection{Analytical procedure}

\subsubsection{Sample preparation}

Following procedure of Cohen et al. (1988), between 100 and $300 \mathrm{mg}$ of powdered rock sample was weighed directly into a PFA (polyfluoroalkoxy) beaker, the exact weight was based on the assumed concentrations of REEs and $\mathrm{Sr}$. The sample was then dissolved on a hot-plate (c. $150^{\circ} \mathrm{C}, 24$ hours) in a $7: 3$ mixture of $29 \mathrm{M} \mathrm{HF}$ and $14 \mathrm{M} \mathrm{HNO}_{3}$. This solution was then repeatedly (3 times) evaporated to dryness and the residue re-dissolved in $0.5 \mathrm{ml}$ of $14 \mathrm{M} \mathrm{HNO}_{3}$. The final residue was dissolved in $8 \mathrm{ml} 6 \mathrm{M} \mathrm{HCl}$ producing a pale yellowish stock solution without any visible particles.
Solution aliquot corresponding to at least $2 \mu \mathrm{g}$ of $\mathrm{Sr}$ and at least $200 \mathrm{ng}$ of $\mathrm{Nd}$ was transferred to another beaker, evaporated to dryness, converted to nitrate by repeat evaporation (3 times) with $250 \mu \mathrm{l}$ of $14 \mathrm{M} \mathrm{HNO}_{3}$, and finally dissolved in $1.5 \mathrm{ml} 2 \mathrm{M} \mathrm{HNO}_{3}$.

\subsubsection{Chromatographic separation of $\mathrm{Sr}$ and LREE}

Column preparation and conditioning The previously prepared columns for separation of Sr and LREE were removed from storage beakers filled with $6 \mathrm{M} \mathrm{HCl}$ and washed with deionised water. The columns were then filled with $0.25 \mathrm{ml}$ of Sr.Spec and TRU.Spec resin slurried in $0.05 \mathrm{M} \mathrm{HNO}_{3}$. The conditioning of the columns was done by passing $2 \times 5 \mathrm{ml}$ of deionised (DI) water, 2 $\mathrm{ml}$ of $0.05 \mathrm{M} \mathrm{HNO}_{3}, 5 \mathrm{ml}$ of deionised water and finally $2 \times 0.5 \mathrm{ml} 2 \mathrm{M} \mathrm{HNO}_{3}$ (Fig. 1).

Sample loading The Sr.Spec column was placed above the TRU.Spec column and the dissolved sample aliquot was loaded into the upper (Sr.Spec) column in three $0.5 \mathrm{ml}$ aliquots of $2 \mathrm{M} \mathrm{HNO}_{3}$. Strontium was retained, in the upper column, while LREE were collected in the lower column filled with the TRU resin. Both columns were then rinsed with $0.5 \mathrm{ml} 2 \mathrm{M} \mathrm{HNO}_{3}$ to remove the matrix elements. Following this step, the two columns were separated and used individually.

Sr elution The Sr.Spec column was washed with $0.5 \mathrm{ml}$ of $2 \mathrm{M} \mathrm{HNO}_{3}$, followed by six $0.5 \mathrm{ml}$ aliquots of $7 \mathrm{M} \mathrm{HNO}_{3}$ and finally with $0.5 \mathrm{ml}$ of $3 \mathrm{M} \mathrm{HNO}_{3}$. Elution of $\mathrm{Sr}$ was done by four $0.5 \mathrm{ml}$ aliquots of $0.05 \mathrm{M} \mathrm{HNO}_{3}$ collected in a precleaned PFA beaker and evaporated to dryness. The residue was treated by addition and subsequent evaporation to dryness of $100 \mu \mathrm{l}$ of $0.05 \mathrm{M}$ $\mathrm{H}_{3} \mathrm{PO}_{4}, 200 \mu \mathrm{l}$ of $7 \mathrm{M} \mathrm{HNO}_{3}$ and $100 \mu 1$ of $\mathrm{H}_{2} \mathrm{O}_{2}$ prior to its loading onto the filament (T. Bullen, personal communication). This $\mathrm{Sr}$ fraction was then ready for analysis on the mass spectrometer. The Sr. Spec resin was washed out of the column with $5 \mathrm{ml}$ of $0.2 \mathrm{M} \mathrm{HCl}$ and stored for regeneration and potential use in future. Empty column with frit was finally backwashed with deionised water and stored in a beaker filled with $6 \mathrm{M} \mathrm{HCl}$ for the next separation.

LREE elution The TRU.Spec column was washed with six $0.5 \mathrm{ml}$ batches of $2 \mathrm{M} \mathrm{HNO}_{3}$ followed by $0.25 \mathrm{ml}$ $0.05 \mathrm{M} \mathrm{HNO}_{3}$ to prevent the $2 \mathrm{M} \mathrm{HNO}_{3}$ to be washed onto the Ln.Spec column that would result in the LREE not being fully retained by Ln.Spec.

\subsubsection{Separation of individual LREE}

Column preparation and conditioning The Ln.Spec columns were taken out from the storage bottle filled with $0.2 \mathrm{M} \mathrm{HCl}$ and washed with $10 \mathrm{ml}$ of $0.2 \mathrm{M} \mathrm{HCl}$ followed 


\section{$\begin{array}{lll}\text { Sr.Spec } & \text { TRU.Spec } & \text { Ln.Spec }\end{array}$}

a) Column conditioning

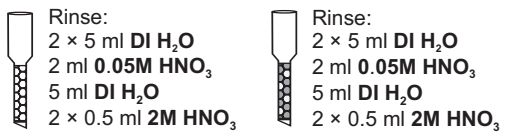

b) Sample loading

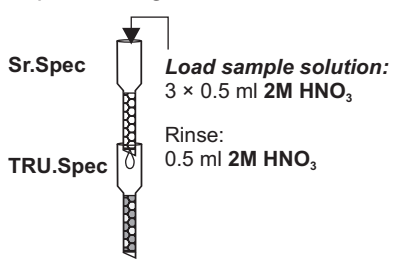

c) Sr elution

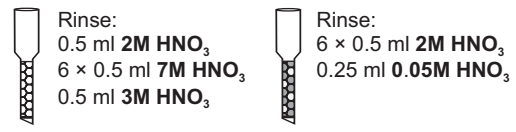

Collect Sr fraction:

$4 \times 0.5 \mathrm{ml} \mathrm{0.05M} \mathrm{\textrm {HNO } _ { 3 }}$

d) Loading LREEs
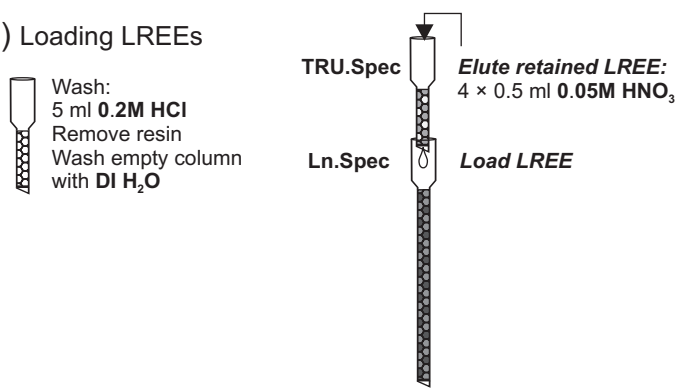

e) Nd elution

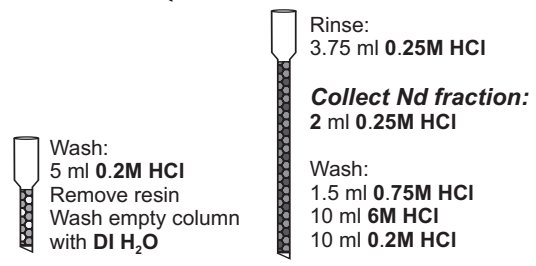

Fig. 1 Strontium and neodymium chromatographic separation scheme. a - conditioning of columns, $\mathbf{b}$ - coupling of Sr.Spec and TRU.Spec column and sample loading on Sr.Spec and TRU.Spec column tandem, $\mathbf{c}$-decoupling of columns and strontium elution, $\mathbf{d}$-coupling of TRU. Spec and Ln.Spec columns and loading of LREEs from TRU.Spec to Ln.Spec, $\mathbf{e}-$ decoupling of columns and neodymium elution

by $10 \mathrm{ml}$ of deionised water. The conditioning was done by washing the column with $2 \mathrm{ml}$ of $0.05 \mathrm{M} \mathrm{HNO}_{3}$.

Sample loading The TRU.Spec column containing the LREE was placed above the preconditioned Ln.Spec column. The LREEs were eluted from the TRU.Spec column with four $0.5 \mathrm{ml}$ aliquots of $0.05 \mathrm{M} \mathrm{HNO}_{3}$ and retained in the Ln.Spec column. Then the columns were decoupled and the TRU.Spec column was treated in the same way as the Sr.Spec column following Sr elution, while the Ln.Spec column was prepared for separation and elution of $\mathrm{Nd}$ and $\mathrm{Sm}$.

Nd elution The Ln.Spec column was washed with $3.75 \mathrm{ml} 0.25 \mathrm{M} \mathrm{HCl}$, the $\mathrm{Nd}$ fraction was eluted using 2 $\mathrm{ml}$ of $0.25 \mathrm{M} \mathrm{HCl}$ and then collected in a precleaned PFA beaker. The $\mathrm{Nd}$ fraction was evaporated to dryness prior to the analysis on the mass spectrometer. The Ln.Spec column was subsequently washed with $1.5 \mathrm{ml}$ of $0.75 \mathrm{M}$ $\mathrm{HCl}$ in order to elute the remaining $\mathrm{Sm}$ and $\mathrm{Eu}$, followed by $10 \mathrm{ml}$ of $6 \mathrm{M} \mathrm{HCl}$ and $10 \mathrm{ml}$ of $0.2 \mathrm{M} \mathrm{HCl}$. The cleaned Ln.Spec column was stored in a bottle filled with $0.2 \mathrm{M}$ $\mathrm{HCl}$.

\subsubsection{Thermal ionisation mass spectrometry}

The $\mathrm{Sr}$ and $\mathrm{Nd}$ isotopic ratios were measured on a Finnigan MAT 262 thermal ionisation mass spectrometer in the Laboratory of Radiogenic Isotopes of the Czech Geological Survey. The instrument operation and data evaluation was done by RunIt 26X software, provided by Spectromat GmbH, Germany.

The Sr sample was loaded onto an out-gassed (i.e. heated in vacuum for 20 minutes to $c .1600^{\circ} \mathrm{C}$ ) Ta filament in $3 \mu 1$ of deionised water. Subsequently it was dried for 8 minutes at $0.8 \mathrm{~A}$, then for 3 minutes at $1.5 \mathrm{~A}$ and finally heated to a pale red glow of the filament until complete dryness (usually for a few seconds at about $3 \mathrm{~A}$ ). The measurement was performed in dynamic (peak jumping) mode using a single filament assembly, and the measured isotopic ratios were corrected for mass dependent instrumental fractionation using exponential law and ${ }^{86} \mathrm{Sr} /{ }^{88} \mathrm{Sr}$ ratio of 0.1194 (Steiger and Jäger 1977). In this mode the evaporation temperature was normally between 1300 and $1350{ }^{\circ} \mathrm{C}$ at the filament current $3 \mathrm{~A}$. A stable ${ }^{88} \mathrm{Sr}$ signal of c. $4 \mathrm{~V}$ was obtained for 40-60 minutes of measurement, corresponding to $70-100$ individual signal scans. The isobaric interference of $\mathrm{Rb}$ at the mass 87 was corrected assuming the natural value 0.3857 for the ${ }^{87} \mathrm{Rb} /{ }^{85} \mathrm{Rb}$ ratio (Steiger and Jäger 1977). However, in the single filament assembly the $\mathrm{Rb}$ signal is normally negligible since the ionisation energy of rubidium is significantly lower than that of strontium. Reproducibility of the isotopic determination is estimated from repeat measurement of the NBS 987 reference material, with an average ${ }^{87} \mathrm{Sr} /{ }^{86} \mathrm{Sr}=$ $0.710247 \pm 26(2 \sigma), \mathrm{n}=25$.

The Nd fraction was dissolved in $3 \mu \mathrm{l}$ of $1 \mathrm{M} \mathrm{HNO}_{3}$ and loaded onto an out-gassed Re filament of a double filament assembly. It was then dried for 8 minutes at $0.8 \mathrm{~A}$, and for 1 minute at $1.1 \mathrm{~A}$. Isotopic analyses were performed in double collector dynamic mode and normalized to ${ }^{146} \mathrm{Nd} /{ }^{144} \mathrm{Nd}=0.7219$. The ionisation filament was heated up to about $1770^{\circ} \mathrm{C}$ and the evaporation filament was heated until the ${ }^{142} \mathrm{Nd}$ signal reached at least $2 \mathrm{~V}$ (usually at a current about 1.6 A). If present, the 
isobaric interference of $\mathrm{Sm}$ at mass 147 was corrected assuming natural isotopic ratio of ${ }^{144} \mathrm{Sm} /{ }^{147} \mathrm{Sm}=0.20648$. External reproducibility of repeat analyses of the La Jolla standard was ${ }^{143} \mathrm{Nd} /{ }^{144} \mathrm{Nd}=0.511852 \pm 14(2 \sigma)$, $\mathrm{n}=23$.

\subsubsection{Inductively coupled plasma mass spectrometry}

Concentrations and elution profiles of elements of interest on Sr.Spec, TRU.Spec and Ln.Spec columns were measured on a single collector, double focusing magnetic sector ICP-mass spectrometer (Thermo Finnigan Element 2) at the Department of Earth Science of the University of Bergen. The eluate was collected for each column in the $0.5 \mathrm{ml}$ batches from the loading of sample onto the column through whole separation sequence. Collected aliquots of eluate were evaporated to dryness and dissolved in $2 \% \mathrm{HNO}_{3}$ prior to analysis. We have added $1 \mathrm{ppb}$ of ${ }^{115}$ In to the samples as an internal standard. Data were acquired in time-resolved acquisition mode with medium mass resolution.

\section{Results and discussion}

Three international silicate reference materials were analysed using the method described above. Analyses of BCR-1 were performed on three different powder aliquots. The results are listed in Tab. 1 and compared with $\mathrm{Sr}$ and Nd reference values GeoReM (http://georem.mpch-mainz.gwdg.de), a Max-Planck-Institut online database. Our experiments are in a good agreement with published values for $\mathrm{Sr}$ as well as for $\mathrm{Nd}$. All measured results fall within 2 sigma range of the published values (Tab. 1) with one exception. The only exception is the measured ${ }^{87} \mathrm{Sr} /{ }^{86} \mathrm{Sr}$ value for the JB-3 reference material, which differs significantly from the only available value published (without given error) by Richardson et al. (1996). Whatever the reason of the difference is (contamination, typo in the paper etc.), it is too large to have originated by the column fractionation.
Procedural blank for $\mathrm{Sr}$ separation was $0.1 \mathrm{ng} \mathrm{Sr}$ and for $\mathrm{Nd}$ separation $0.025 \mathrm{ng} \mathrm{Nd}$. Note that the sample load was equivalent to the $2 \mu \mathrm{g} \mathrm{Sr}$ and $200 \mathrm{ng} \mathrm{Nd}$.

We had also measured elution intervals for the freshly prepared columns as well as for used Ln.Spec columns. The results are summarised in Figures 2 and 3. Ln.Spec column elution profile in Fig. 2 and results for Sr.Spec and TRU.Spec are summarized in Fig. 3. Our experiments suggest that the elution curves for the Sr.Spec and TRU.Spec columns are stable during time, and follow the elution scheme as presented in Fig. 3. In agreement with Pin and Zalduegui (1997) we have also found that the Ln.Spec resin can be reused. However, the yields of $\mathrm{Nd}$ decreased significantly after roughly half a year of

a) new column

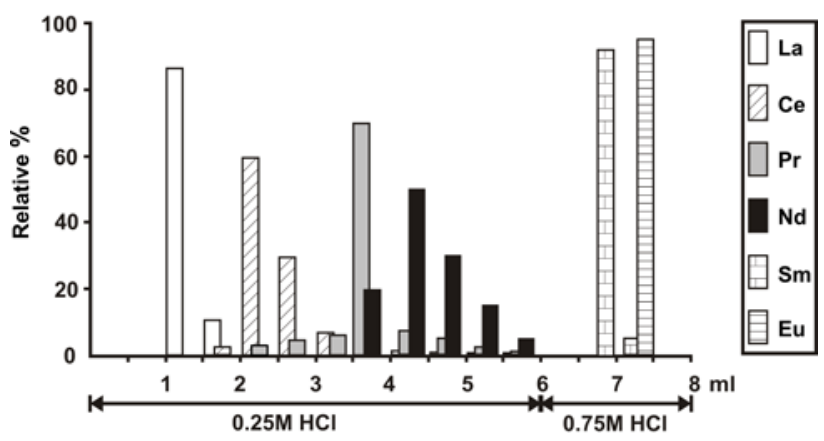

b) used column

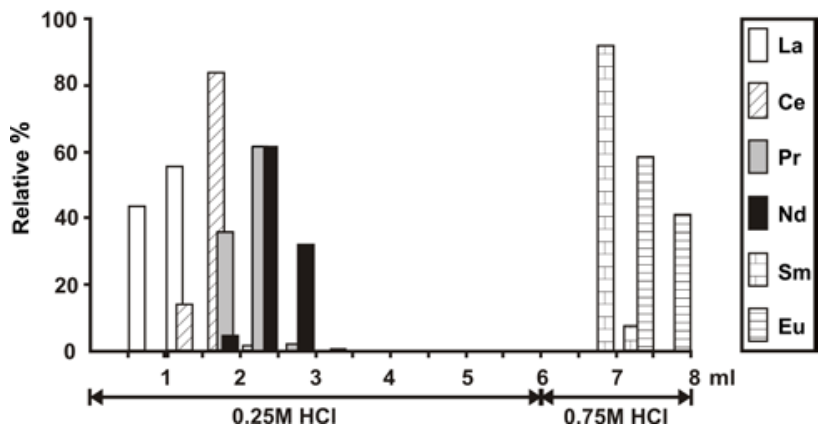

Fig. 2 Diagram showing elution profile of LREE on Ln.Spec column. a - column packed with new resin, $\mathbf{b}$ - column after about a half a year of use

Tab. 1 The Sr and Nd isotopic data for international silicate reference materials. Analytes were separated on Sr.Spec, TRU.Spec and Ln.Spec columns. Reference values are from GeoReM online database (http://georem.mpch-mainz.gwdg.de). Uncertainties of our measurements are given as 2 standard errors of the mean, corresponding to statistical uncertainties of $95 \%$.

\begin{tabular}{lcccccc}
\hline $\begin{array}{l}\text { Reference } \\
\text { material }\end{array}$ & $\mathbf{S r}(\boldsymbol{\mu g} / \mathbf{g})$ & $\mathbf{N d}(\boldsymbol{\mu g} / \mathbf{g})$ & ${ }^{87} \mathbf{S r}{ }^{8{ }^{8} \mathbf{S r}}$ & ${ }^{87} \mathbf{S r}{ }^{86} \mathbf{S r}_{\text {GeoReM }}$ & ${ }^{143} \mathbf{N d} /{ }^{144} \mathbf{N d}$ & ${ }^{143} \mathbf{N d} /{ }^{144} \mathbf{N d}{ }_{G e o R e M}$ \\
\hline BCR-1 & 330 & 28 & $0.704999 \pm 13$ & $0.70502 \pm 2(\mathrm{SD})$ & $0.512630 \pm 12$ & $0.51264 \pm 2(\mathrm{SD})$ \\
& & & $0.705007 \pm 13$ & & $0.512616 \pm 18$ & \\
& & & $0.705004 \pm 8$ & & $0.512630 \pm 9$ & \\
JA-1 & 260 & 10 & $0.703549 \pm 9$ & $0.70360 \pm 6(2 \mathrm{SE})$ & $0.513079 \pm 8$ & $0.51383 \pm 6(2 \mathrm{SE})$ \\
JB-3 & 400 & 15 & $0.703409 \pm 12$ & $0.70351 \pm$ not given & $0.513050 \pm 10$ & $0.51305 \pm$ not given \\
\hline
\end{tabular}


a) Elution Sr.Spec column

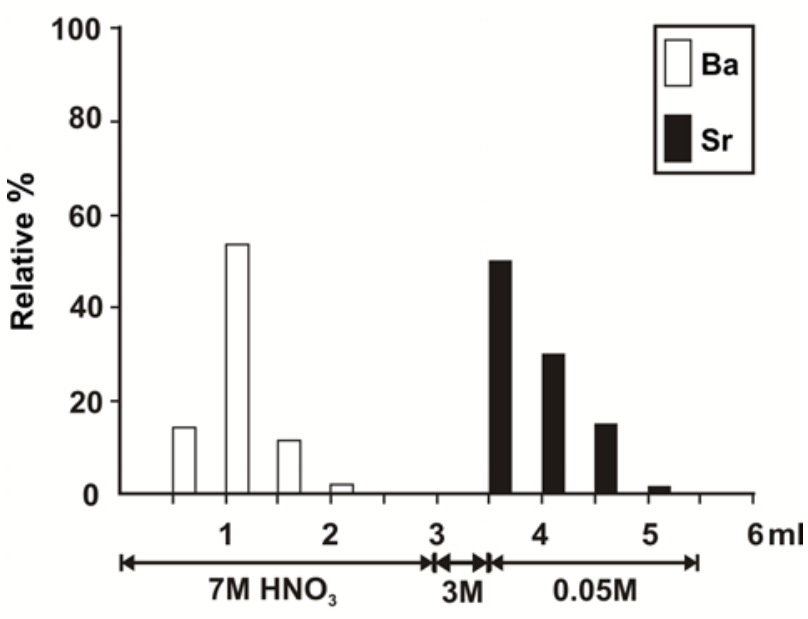

b) Elution TRU.Spec column

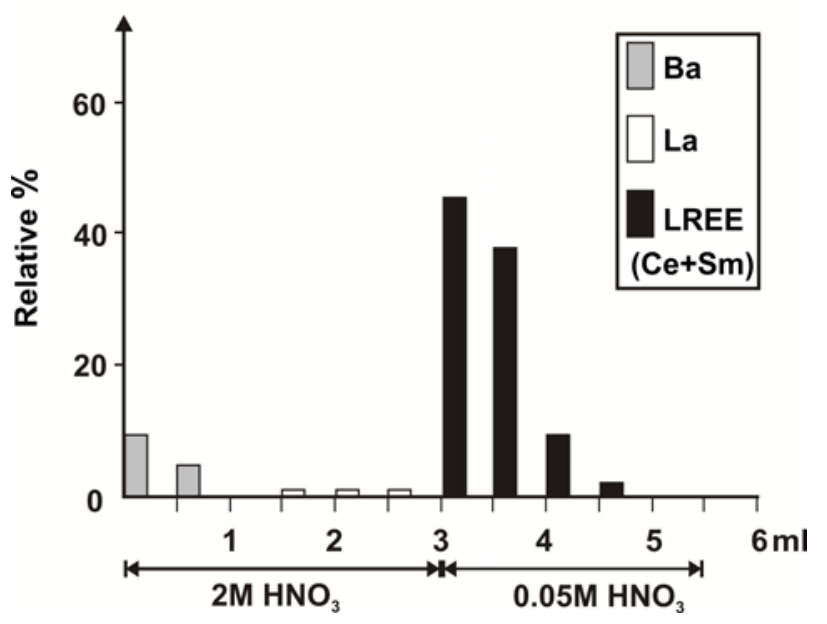

Fig. 3 Diagram showing elution profile of $\mathbf{a}-\mathrm{Sr}$.Spec column, $\mathbf{b}-\mathrm{TRU}$. Spec column

the column use, suggesting a change of elution curves over time. Because of this, we made additional measurements of elution intervals for individual LREEs, following a period of use of the Ln.Spec. Results of these measurements (Fig. 2b) show the elution of La, Ce, Pr and $\mathrm{Nd}$ using the same strength of acid $(0.25 \mathrm{M} \mathrm{HCl})$. It starts earlier, and the elution window for this group of elements is significantly narrower, compared to the fresh made columns. Following sample loading onto columns and rinsing with $0.5 \mathrm{ml}$ of $0.25 \mathrm{M} \mathrm{HCl}, c .98 \%$ of La was detected in the next $1 \mathrm{ml}$ of $0.25 \mathrm{M} \mathrm{HCl}$. The subsequent $0.5 \mathrm{ml}$ of La elution overlapped with the onset of Ce elution and contained approximately $14 \%$ of Ce present in the sample aliquot. Most of Ce (c. $83 \%)$ present in the sample solution was found in the subsequent $0.5 \mathrm{ml}$ of $0.25 \mathrm{M} \mathrm{HCl}$ together with c. $35 \%$ of Pr and c. $5 \%$ of
$\mathrm{Nd}$. The following $0.5 \mathrm{ml}$ of eluate contained almost the same amounts (c. $62 \%$ ) of $\mathrm{Pr}$ and $\mathrm{Nd}$. The remaining $\mathrm{Nd}$ and traces of Pr were eluted with the following $0.5 \mathrm{ml}$ batch of $0.25 \mathrm{M} \mathrm{HCl}$. Collectively, the elution window for LREEs was $3 \mathrm{ml}$ of $0.25 \mathrm{M} \mathrm{HCl}$, which is $2 \mathrm{ml}$ less compared to the elution using a fresh Ln.Spec resin (Fig. 2a). This results in a poor separation because of overlapping elution intervals for individual elements. No detectable Sm was found during this separation step.

After passing $6 \mathrm{ml}$ of $0.25 \mathrm{M} \mathrm{HCl}$ required for a good separation of $\mathrm{Nd}$ through the freshly prepared Ln.Spec columns, the elution acid was changed to $0.75 \mathrm{M} \mathrm{HCl}$. The elution of Sm started after passing $0.5 \mathrm{ml}$ of $0.75 \mathrm{M}$ $\mathrm{HCl}$ and about $92 \%$ of $\mathrm{Sm}$ in the sample solution aliquot was eluted in following $0.5 \mathrm{ml}$ of this acid. The remaining $8 \%$ of Sm and c. $58 \%$ of Eu were washed out in the subsequent $0.5 \mathrm{ml}$ fraction. The columns were then rinsed and $10 \mathrm{ml}$ of $6 \mathrm{M} \mathrm{HCl}$ eluate was collected, evaporated to dryness and analysed as sample. The eluate contained $c$. $40 \%$ of Eu, which overlapped the separation interval on fresh Ln.Spec resin. Irrespective of aging of the resin, Sm was well separated from $\mathrm{Nd}$, due to different strengths of elution agents. Results of this experiment suggest that the retention efficiency of Ln.Spec decreases significantly with use, pointing to the necessity of periodical yield checks.

In addition to using the proposed $\mathrm{Sr}$ separation scheme for silicate rock samples, it was also successfully applied to $\mathrm{Sr}$ separation from biogenic phosphates during interlaboratory study of a new reference material organized by National Oceanography Centre in Southampton (Chavagnac 2007). The results of fifteen repeat analyses of the bone phosphate were consistent both internally and externally with the results of other six laboratories that took part in the study (Chavagnac in prep.).

\section{Conclusions}

Combination and modification of several previously published $\mathrm{Sr}$ and $\mathrm{Nd}$ separation procedures led to establishing a chromatographic separation scheme that is optimised for the needs of radiogenic isotope laboratory in Czech Geological Survey. The main benefits of this procedure are better separation of REE from the silicate rock sample matrix and improvements in accuracy and reproducibility of both $\mathrm{Sr}$ and $\mathrm{Nd}$ TIMS measurements. The quantities of acids and resin required for the separation as well as the separation time were significantly reduced. The complete chemical separation of $\mathrm{Sr}$ and $\mathrm{Nd}$ can now be achieved in a single, rather than three days and total consumption of acids was reduced from 160 to $70 \mathrm{ml}$. Special attention must be paid to the elution shift of calibrated Ln.Spec columns as it could result in poor LREE separation. 
Acknowledgements The authors would like to thank to their colleague Vojtěch Erban from the Czech Geological Survey for his help and guidance in TIMS measurements. This study was supported by the Czech Geological Survey internal project No. 3319. We are grateful to Jan Košler and an anonymous reviewer for their detailed and constructive comments, which substantially improved the manuscript.

\section{References}

Aldrich LT, Doak JB, Davis GL (1953) The use of ion exchange columns in mineral analysis for age determination. Am J Sci 251: 377-387

Chavagnac V, Milton JA, Green DRH, Breuer J, Bruguier O, Jacob DE, Jong T, Kamenov GD, Le Huray J, Liu Y, Palmer Mr, Pourtales S, Roduhskin I, Soldati A, TRUEMAN CN, YuAn H (2007) Towards the development of a fossil bone geochemical standard: an inter-laboratory study. Anal Chim Acta, 599: 177-190.

Cohen AS, O’Nions RK, Seigenthaler R, Griffin WL
(1988) Chronology of the pressure-temperature history recorded by a granulite terrain. Contrib Mineral Petrol 98: 303-311

Pin C, Zalduegui JFS (1997) Sequential separation of light rare-earth elements, thorium and uranium by miniaturized extraction chromatography: application to isotopic analyses of silicate rocks. Anal Chim Acta 339: 79-89

Pin C, Briot D, Bassin C, Poitrasson F (1994) Concominant separation of strontium and samarium-neodymium for isotopic analysis in silicate samples, based on specific extraction chromatography. Anal Chim Acta 298: 209-217

Richard P, Shimizu N, Allègre CJ (1976) ${ }^{143} \mathrm{Nd} /{ }^{146} \mathrm{Nd}$, a natural tracer: an application to oceanic basalts. Earth Planet Sci Lett 31: 269-278

Richardson JM, Lightfoot PC, De Souza H (1996) Current geoscience laboratories geoanalytical programs and their quality assurance underpinnings. Geost Newslett 20: $141-156$

Steiger R H, JäGer E (1977) Subcommission on Geochronology; convention on the use of decay constants in geo- and cosmochronology. Earth Planet Sci Lett 36: 359-362

\section{Modifikovaný postup chromatografické separace Sr a Nd ze silikátových geologických vzor- ků pro účely izotopové analýzy}

Nový postup chromatografické separace $\mathrm{Sr}$ a Nd z geologických silikátových vzorků byl zaveden a úspěšně otestován pro běžné použití v laboratoři radiogenních izotopů České geologické služby. Schéma separace je založeno na kombinaci a modifikaci metod publikovaných v článcích Christiana Pina a jeho spolupracovníků. Kombinací tří chromatografických kolon do jedné procedury je možné během pracovního dne získat čisté frakce stroncia a neodymu (v případě zájmu také samaria) z poměrné části rozpuštěného horninového vzorku. Celkový výtěžek separace je vysoký, při zachování nízkých hodnot procedurálního blanku. Tento separační postup minimalizuje spotřebu kyselin a pracovního času nutného k provedení separace na méně něž polovinu ve srovnání s předchozím tradičně používaným postupem. Je nutné pravidelně kontrolovat kalibrační křivky kolon naplněných Ln.Spec ionexem, protože po určité době jejich intenzivního užívání dochází k posunu elučních intervalů jednotlivých prvků ze skupiny lehkých vzácných zemin. Vhodnost použití tohoto postupu pro separaci Sr a Nd ze silikátových horninových vzorků byla ověřena opakovaným měřením izotopických poměrů ${ }^{87} \mathrm{Sr} /{ }^{86} \mathrm{Sr}$ a ${ }^{143} \mathrm{Nd} /{ }^{144} \mathrm{Nd}$ pro tři mezinárodní referenční materiály BCR-1, JA-1 a JB-3. 